\title{
The response of rats to long-term feeding with diets containing oxidized fat. 2 . Biochemical indicators in the serum, liver, and bone mineralization*
}

\author{
J. Juśkiewcz', M. Dlugoszewska' ${ }^{1}$, Z. Zduńczyk ${ }^{1}$, \\ A. Krasnodębska-Depta ${ }^{2}$, B. Krefft ${ }^{1}$ and J. Sadowska ${ }^{1}$ \\ Institute of Animal Reproduction and Food Research, \\ Division of Food Science. Polish Academy of Sciences \\ Tuwima 10, 10-747 Olsztyn. Poland \\ ${ }^{2}$ Faculty of Veterinary Medicine, Warmian and Mazurian University in Olsztyn \\ Oczapowskiego 13, 10-957 Olsztyn, Poland
}

(Received 16 March 1999; accepted 13 January 2000)

\begin{abstract}
Selected biochemical indicators in blood and liver and indicators of femur mineralization were determined in rats fed for eight weeks on diets containing $10 \%$ fat with a peroxide value below 5,40 , $80,120,160$, or $200 \mathrm{meq} \mathrm{O}_{2} / \mathrm{kg}$. The average body weight of the rats was $259.9 \pm 10.5 \mathrm{~g}$, the experimental groups contained 12 animals. Fat with a high peroxide value ( 160 and $200 \mathrm{meq} \mathrm{O} / \mathrm{kg}$ ) significantly increased the concentration of malondialdehyde in the serum and slightly in the liver. The most sensitive indicators of the reaction of rats to oxidation of dietary fat were the activity of glutathione peroxidase in erythrocytes, which increased with the rising degree of dietary fat oxidation, i.e. at $40 \mathrm{meq} \mathrm{O}_{2} / \mathrm{kg}$, the activity of serum aspartate aminotransferase and the vitamin $\mathrm{A}$ content in the liver, which fell at a peroxide value of $80 \mathrm{meq} \mathrm{O}_{2} / \mathrm{kg}$. A less sensitive indicator was erythrocyte peroxide dismutase activity, which did not increase until fat with a peroxide value of $160 \mathrm{meq} \mathrm{O}_{2} / \mathrm{kg}$ was fed. The degree of fat oxidation did not significantly affect the activity of serum alanine aminotransferase, liver enzymes (aspartate aminotransferase, alanine aminotransferase, acid phosphatase, and lactate dehydrogenasc), serum and liver triglycerides levels, total cholesterol and HDL cholesterol, or femur mineralization indicators.
\end{abstract}

KEY WORDS: rats, lipid peroxidation, serum, liver lipids, enzymes, bone mineralization

* Supported by the State Commitee for Scientific Research, Grant No 5PO6E 02013 


\section{INTRODUCTION}

The results of studies implicating free radicals in the pathogenesis of numerous diseases (Baynes, 1991; Kehrer, 1993) have led to increased interest in the quality of dietary fat in human and animal nutrition. Numerous studies have shown that the composition and degree of oxidation of consumed fat has an adverse effect on liver cell function (Lambert et al., 1998) and lipid metabolism (Sanchez-Muniz et al., 1998). Oxidized dietary fat can disturb many metabolic processes (Corcos Benedetti et al., 1987), among others, by inducing oxidation of membrane lipids (Hayam et al., 1987). If the oxidation of fats is extensive, leading to formation of polymerized and cyclic derivatives, a very distinct adverse impact of this kind of fat on feed intake, growth, and liver secretory function becomes apparent (LopezVarela et al., 1995). The harmful consequences of feeding fat with lesser degrees of oxidation without polymers are still little recognized. Many studies have indicated that the detrimental effect of such fat on feed intake and animal growth may be small (Hochgraf et al., 1997; Zduńczyk et al., 2000).

The objective of this study was to investigate the response of rats to long-term ( 8 weeks) feeding with diets containing fat oxidized to various degrees. Selected biochemical indicators in blood and liver and mineralization indicators in the femur were analyzed as the indicators of metabolic changes caused by oxidized dietary fat.

\section{MATERIAL AND METHODS}

\section{Animals and diets}

The study was conducted on six groups of rats fed for eight weeks with diets containing $10 \%$ fat with peroxide values of under $5,40,80,120,160$, $200 \mathrm{meq} \mathrm{O}_{2} / \mathrm{kg}$. The average body weight of the rats was $259.9 \pm 10.5 \mathrm{~g}$, the experimental group numbered 12 animals. Details of the diet composition, conditions of oxidizing fat, feed consumption and utilisation, and growth of rats are given in the preceding paper (Zduńczyk et al., 2000).

\section{Preparation of samples}

The rats were anaesthetized with a $20 \%$ solution of urethane (Sigma), then blood was sampled and the liver and femur were isolated. The activities of superoxide dismutase (SOD) and glutathione peroxidase (PGx) were assayed immediately in erythrocytes of blood sampled into heparinized tubes. Unheparinized blood was left at room temperature to coagulate and the serum was removed by 
centrifugation at $2500 \mathrm{~g} / \mathrm{min}$ for $15 \mathrm{~min}$. Serum and isolated liver (weighed and frozen in liquid nitrogen) were stored at $-40^{\circ} \mathrm{C}$ until analysis.

\section{Analytical methods}

Superoxide dismutase (SOD) and glutathione peroxidase (PGx) activities were assayed using kits from Randox Laboratories Ltd. (Cat. No. SD125 and No. RS505, respectively). The activity of aspartate aminotransferase (AST) and alanine aminotransferase (ALT) as well as the serum triglycerides (TAG), total cholesterol (TC) and HDL fractions were determined using kits from Alpha Diagnostics. The content of malondialdehyde (MDA) in serum was determined spectrophotometrically using a Beckman (model DV 7500) spectrophotometer, by analyzing the reaction products with tiobarbituric acid (TBA) by the Yaga method (1980). In order to assay TAG, total and HDL cholesterol fractions in the liver, preliminary extraction of lipids with a 2:1 mixture of chloroform-methanol was carried out according to Folch et al. (1957), then as described by Prasad and Saraswathy (1996). The MDA content in liver tissue was determined spectrophotometrically using the method of Uchiyama and Mihara (1978).

The activities of aspartate (AST) and alanine (ALT) aminotransferase, alkaline phosphatase (AP) and lactate dehydrogenase (LDH) in the liver were determined using Alpha Diagnostics kits, after preparation of a liver homogenate according to the method of Rivetz and Bogin (1982), Farnson et al. (1985), and Webb et al. (1991). The vitamin A content of liver was determined by HPLC according to Cuesta Sanz and Castro Santa-Gruz (1986).

Femur mineralization was evaluated using two indicators, $\mathrm{Ca}$ and $\mathrm{P}$ contents and breaking resistance. The breaking force was determined using an INSTRON (model 1011) apparatus. After ashing the bone at a temperature of $450^{\circ} \mathrm{C}$, the calcium content of the ash was determined using a diagnostic kit from Alpha Diagnostics, while phosphorus was determined by the method of Fiske and Subbarow (Tomaszewski, 1970).

The results were subjected to statistical analysis using one-way analysis of variance and the Duncan multiple range test.

\section{RESULTS AND DISCUSSION}

The blood triglyceride levels (TAG) and total serum cholesterol (TC) were similar in all groups (Table 1). A significant reduction of the serum HDL fraction from $57.8 \mathrm{mg} / \mathrm{dl}$ in the control group (I) to $51.1-51.4 \mathrm{mg} / \mathrm{dl}$ in the groups receiving diets containing fats with peroxide value of 160 and $200 \mathrm{meq} \mathrm{O}_{2} / \mathrm{kg}$ (groups $\mathrm{V}$ and VI) was found. The TAG content (from 64.1 to $65.9 \mathrm{mg} / \mathrm{dl}$ ) and serum cholesterol 
(from 73.0 to $78.1 \mathrm{mg} / \mathrm{dl}$ ) were similar to that in rats fed diets with a similar amount of fat ( $9 \%$ ) from various sources (Kirchgessner et al., 1993). In the experiment of Sanchez-Muniz et al. (1998) a 15\% addition of oxidized sunflower oil to diets caused a significant rise in total serum cholesterol in comparison with a group fed non-oxidized oil. Also in the experiment of Hochgraf et al. (1997) highly oxidized dietary fat ( $1300 \mathrm{meq} \mathrm{O}_{2} / \mathrm{kg}$ fat) elevated serum cholesterol levels in rats.

Rats fed diets containing fat with peroxide value of 160 and $200 \mathrm{meq} \mathrm{O}_{2} / \mathrm{kg}$ (groups V and VI) had significantly higher serum malondialdehyde (MDA) concentrations (Table 1), most likely as the result of absorption of an increased amount of peroxide degradation products.

TABLE 1

Triglycerides (TAG), total cholesterol (TC), HDL-cholesterol (HDL-C) and malondialdehyde (MDA) content in serum of rats'

\begin{tabular}{|c|c|c|c|c|c|c|c|}
\hline & \multicolumn{6}{|c|}{ Group 2} & \multirow{2}{*}{ SEM } \\
\hline & I & 11 & III & IV & V & VI & \\
\hline $\mathrm{TAG}, \mathrm{mg} / \mathrm{dl}$ & 68.5 & 64.1 & 65.9 & 65.5 & 65.9 & 65.4 & 1.256 \\
\hline $\mathrm{TC}, \mathrm{mg} / \mathrm{d}]$ & 78.1 & 73.0 & 74.2 & 75.0 & 75.7 & 74.8 & 1.202 \\
\hline HDL-C, $\mathrm{mg} / \mathrm{d}]$ & 57.8 & 52.7 & 53.6 & 55.7 & 51.1 & 51.4 & 0.759 \\
\hline $\mathrm{MDA}, \mu \mathrm{g} / \mathrm{ml}$ & $0.401^{\mathrm{ABbc}}$ & $0.361^{\mathrm{Ac}}$ & $0.405^{\mathrm{ABb}}$ & $0.395^{\mathrm{ABbc}}$ & $0.494^{\mathrm{ABab}}$ & $0.506^{\mathrm{Aa}}$ & 0.014 \\
\hline
\end{tabular}

1 values represent means and standard error of the mean (SEM), $n=12$

2 peroxide value of fat introduced into diets of particular groups was: below 5, 40,80, 120160 and $200 \mathrm{mcq} \mathrm{O}_{2} / \mathrm{kg}$, respectively

a. h $-\mathrm{P}<0.05$

A. $8-P<0.01$

Table 2 presents data on the activity of selected enzymes in serum and erythrocytes. In rats fed diets containing fat oxidized to $80-200 \mathrm{meq} \mathrm{O}_{2} / \mathrm{kg}$ (groups III-VI), a significant reduction of serum aspartate aminotransferase (AST) activity from $204.9 \mathrm{U} / \mathrm{dl}$ in the control group to $164.6-176.1 \mathrm{U} / \mathrm{dl}$ was found. The activity of alanine aminotransferase (ALT) did not differ among groups and ranged from 44.5 to $50.3 \mathrm{U} / \mathrm{dl}$. The activities of AST and ALT in the serum were close to the values obtained by Nalbone et al. (1989), who fed rats diets with a high $(17 \%)$ fat content.

Greater fat oxidation caused a distinct rise in the activity of superoxide dismutase (SOD) and glutathione peroxidase (PGx) in erythrocytes. In group VI, in which rats were fed a diet containing fat with a peroxide value of $200 \mathrm{meq} \mathrm{O}_{2} / \mathrm{kg}$, PGx in erythrocytes demonstrated an activity of $1021 \mathrm{U} / \mathrm{dl}$, SOD of $429 \mathrm{U} / \mathrm{ml}$, while in the control group, the respective activities of these enzymes were $609 \mathrm{U} / \mathrm{dl}$ and $311 \mathrm{U} / \mathrm{ml}$. Hayam et al. (1995) also found higher SOD and PGx activities in erythrocytes of rats fed for 7 weeks soyabean oil oxidized to a pero- 
TABLE 2

The activity of plasma aspartate aminotransferase (AST), alanine aminotransferase (ALT) and erythrocyle superoxide dismutase (SOD) and glutathione peroxidase (PGX)

\begin{tabular}{|c|c|c|c|c|c|c|c|}
\hline & \multicolumn{6}{|c|}{ Group ${ }^{2}$} & \multirow{2}{*}{ SEM } \\
\hline & 1 & II & III & IV & V & VI & \\
\hline AST, U/dl & $204.9^{a}$ & $180.6^{a b}$ & $176.1^{\mathrm{b}}$ & $170.9^{\mathrm{b}}$ & $164.9^{\mathrm{h}}$ & $164.6^{\mathrm{b}}$ & 3.74 \\
\hline $\mathrm{ALT}, \mathrm{U} / \mathrm{d}]$ & 44.5 & 45.5 & 46.3 & 50.3 & 49.8 & 50.1 & 1.62 \\
\hline PGx, U/d] & $609.1^{\mathrm{Aa}}$ & $835.3^{\wedge \mathrm{Bb}}$ & $851.2^{\mathrm{ABb}}$ & $817.0^{\mathrm{ABb}}$ & $905.3^{\mathrm{Bb}}$ & $1020.9^{8 b}$ & 30.39 \\
\hline $\mathrm{SOD}, \mathrm{U} / \mathrm{ml}$ & $311.3^{\mathrm{Aa}}$ & $345.1^{\mathrm{ABa}}$ & $382.5^{\text {A }}$ & $370.0^{\mathrm{ABab}}$ & $426.0^{\mathrm{Bb}}$ & $428.7^{\mathrm{Bb}}$ & 10.91 \\
\hline
\end{tabular}

1 values represent means and standard error of the mean (SEM), $n=12$

2 peroxide value of fat introduced into diets of particular groups was: below 5, 40, 80, 120160 and $200 \mathrm{meq} \mathrm{O}_{2} / \mathrm{kg}$, respectively

a. $\mathrm{b}-\mathrm{P}<0.05{ }^{\mathrm{A} . \mathrm{B}}-\mathrm{P}<0.01$

xide value of $420 \mathrm{meq} \mathrm{O}_{2} / \mathrm{kg}$, in comparison with a group fed non-oxidized oil. These authors also observed a concomitant increase in the activities of serum alanine (ALT) and aspartate (AST) aminotransferases.

The results given in Table 2 indicate that the most sensitive indicators of a biological reaction of rats to oxidation of dietary fat was glutathione peroxidase, whose activity increased when the peroxide value of dietary fat was only $40 \mathrm{meq} \mathrm{O}_{2} / \mathrm{kg}$, and aspartate aminotransferase (activity lowered at a peroxide value of $80 \mathrm{meq} \mathrm{O}_{2} / \mathrm{kg}$ ), while the least sensitive indicator was superoxide dismutase, whose activity did not decline until the peroxide value of dietary fat reached $160 \mathrm{meq} \mathrm{O}_{2} / \mathrm{kg}$. The degree of dietary fat oxidation did not affect the activity of serum alanine aminotransferase.

Increasing the oxidation of dietary fat did not cause changes in the weight of the liver or its fat, triglyceride, or cholesterol contents (Table 3). The triglyceride content ranged from 12.2 to $14.7 \mathrm{mg} / \mathrm{g}$, total cholesterol, $3.1-3.2 \mathrm{mg} / \mathrm{g}$ liver, and was similar to the content of these compounds in the liver of rats that were fed $10 \%$ non-oxidized animal fat or sunflower seed oil (Nagata et al., 1980; Wachnik et al., 1989). The content of HDL-cholesterol in the liver of animals fed diets containing the most highly oxidized fat $\left(200 \mathrm{meq} \mathrm{O}_{2} / \mathrm{kg}\right)$ was $1.55 \mathrm{mg} / \mathrm{g}$ and was lower than in the remaining groups $(1.80-1.96 \mathrm{mg} / \mathrm{g})$. The MDA content of the liver was highest in rats fed the diets with the highest level of fat oxidation (groups $\mathrm{V}$ and VI, difference nonsignificant). In the experiments of Sanchez-Muniz et al. (1998) and Hochgraf et al. (1997) feeding rats diets containing highly oxidized fat caused a significant increase in the MDA content of the liver. In the studies of Hochgraf et al. (1997) a concomitant significant fall in the cholesterol content of the liver was found as compared with animals fed unoxidized fat, whereas in the experiment of Corcos Benedetti et al. (1987), replacing part of fresh fat with oxi- 
TABLE 3

Liver weight, triglycerides (TAG), total cholesterol, (TC), HDL-cholesterol (HDL-C) and malondialdehyde (MDA) content in the liver'

\begin{tabular}{|c|c|c|c|c|c|c|c|}
\hline & \multicolumn{6}{|c|}{ Group $^{2}$} & \multirow{2}{*}{ SEM } \\
\hline & J & II & III & IV & V & VI & \\
\hline Liver weight, g/100 BW & 3.43 & 3.46 & 3.36 & 3.50 & 3.45 & 3.53 & 0.026 \\
\hline Fat content. $\%$ & 4.68 & 4.37 & 4.61 & 4.50 & 4.73 & 4.55 & 0.035 \\
\hline $\mathrm{TAG}, \mathrm{mg} / \mathrm{g}$ & 13.77 & 12.17 & 14.72 & 14.22 & 13.32 & 13.94 & 0.339 \\
\hline $\mathrm{TC}, \mathrm{mg} / \mathrm{g}$ & 3.12 & 3.21 & 3.18 & 3.05 & 3.11 & 3.07 & 0.042 \\
\hline $\mathrm{HDL}-\mathrm{C}, \mathrm{mg} / \mathrm{g}$ & 1.89 & 1.96 & 1.83 & 1.80 & 1.80 & 1.55 & 0.054 \\
\hline $\mathrm{MDA}, \mu \mathrm{g} / \mathrm{g}$ & 6.39 & 6.19 & 6.21 & 6.52 & 6.56 & 6.76 & 0.075 \\
\hline
\end{tabular}

1 values represent means and standard error of the mean (SEM), $n=12$

${ }^{2}$ peroxide value of fat introduced into diets of particular groups was: below 5, 40, 80, 120160 and 200 meq $\mathrm{O}_{2} / \mathrm{kg}$, respectively

dized and polymerized soyabean oil did not cause significant changes in serum and liver MDA contents.

Table 4 presents results pertaining to the activity of selected liver enzymes. No differences were found in the activity of alanine and aspartate aminotransferases, but there was a tendency towards a declining activity of alkaline phosphatase, from $3.97 \mathrm{U} / \mathrm{g}$ in group I to $3.05-3.11 \mathrm{U} / \mathrm{g}$ in groups IV-VI, i.e. as the dietary fat became more oxidized. In the case of $\mathrm{LDH}$, a reverse relationship was found, i.e. the activity of this enzyme rose as the diet contained more oxidized fat, but the differences among groups did not reach statistical significance. Feeding rats oxidized fat caused a significant reduction in the vitamin A content of the liver from

TABLE 4 Aspartate aminotransferase (AST), alanine aminotransferase (ALT), alkaline phosphatase (AP), lactate dehydrogenase (LDH) and vitamin A content in liver ${ }^{1}$

\begin{tabular}{lcccccccc}
\hline & \multicolumn{7}{c}{ Group $^{2}$} & \multirow{2}{*}{ SEM } \\
\cline { 2 - 7 } & I & II & III & IV & V & VI & \\
\hline AST, U/g & 108.6 & 114.4 & 103.9 & 111.1 & 111.6 & 110.8 & 4.395 \\
ALT, U/g & 73.6 & 70.5 & 76.0 & 70.7 & 75.6 & 72.4 & 2.193 \\
AP, U/g & 3.97 & 3.61 & 3.18 & 3.05 & 3.11 & 3.07 & 0.042 \\
LDH, U/g & 439.66 & 434.25 & 453.78 & 457.51 & 475.86 & 461.51 & 10.112 \\
Vitamin A, mg/100 g & $85.07^{\mathrm{Aa}}$ & $83.67^{\wedge \mathrm{Ba}}$ & $67.91^{\mathrm{BCb}}$ & $61.92^{\mathrm{Cbc}}$ & $63.56^{\mathrm{Chc}}$ & $52.94^{\mathrm{Ci}}$ & 2.129 \\
\hline
\end{tabular}

1 values represent means and standard crror of the mean (SEM), $n=12$

2 peroxide value of fat introduced into diets of particular groups was: below 5, 40, 80, 120160 and $200 \mathrm{meq} \mathrm{O}_{2} / \mathrm{kg}$, respectively

a.b $-\mathrm{P}<0.05 ;{ }^{\mathrm{ABC}}-\mathrm{P}<0.01$ 
$85.1 \mathrm{mg} / 100 \mathrm{~g}$ in group I to $52.9 \mathrm{mg} / 100 \mathrm{~g}$ in group VI; a significant reduction was already noted after feeding the diet containing fat oxidized to a peroxide value of $80 \mathrm{meq} \mathrm{O}_{2} / \mathrm{kg}$. A similar decline in vitamin A content in the liver of rats was found in a study by Corcos Benedetti et al. (1987), in which part of fresh fat was replaced with a oxidized fraction of soyabean oil.

No unequivocal dependence between the degree of oxidation of dietary fat and the calcium and phosphorous contents of the femur in rats was found (Table 5). The breaking strength of the femur was similar in groups I-V, the lowest in group VI, but these differences were not statistically significant. The lowest breaking strength of the femur in group VI was in line with the lowest calcium and phosphorous content in bone tissue. In this group fat digestibility was also significantly worse (Zduńczyk et al., 2000), which could have caused the increased excretion of calcium soaps in faeces (Matyka and Korol, 1991).

TABLE 5

Calcium and phosphorus content (\% of bone ash) and breaking force of the rat femur'

\begin{tabular}{lccccccc}
\hline & \multicolumn{9}{c}{ Degree of fat oxidation, meq $\mathrm{O}_{2} / \mathrm{kg}$} & \multirow{2}{*}{ SEM } \\
\cline { 2 - 7 } & 5 & 40 & 80 & 120 & 160 & 200 & \\
\hline $\mathrm{Ca}$ & $38.34^{\mathrm{ab}}$ & $38.14^{\mathrm{ab}}$ & $38.83^{\mathrm{a}}$ & $37.24^{\mathrm{b}}$ & $38.00^{\mathrm{ab}}$ & $36.94^{\mathrm{b}}$ & 0.203 \\
$\mathrm{P}$ & 16.41 & 16.30 & 16.13 & 16.51 & 16.65 & 16.11 & 0.070 \\
Femur breaking force (Newton) & 84.00 & 84.49 & 85.87 & 86.50 & 85.85 & 81.87 & 1.229 \\
\hline
\end{tabular}

1 values represent means and standard error of the mean (SEM), $n=12$

2 peroxide value of fat introduced into diets of particular groups was: below 5, 40, 80, 120160 and $200 \mathrm{meq} \mathrm{O}_{2} / \mathrm{kg}$, respectively

a, b $-\mathrm{P}<0.05$

\section{CONCLUSIONS}

The results of this study show that the most sensitive indicators of a response of rats to oxidation of dietary fat are erythrocyte glutathione peroxidase activity, which increased with rising degree of dietary fat oxidation, i.e. when fat with a peroxide value of $40 \mathrm{meq} \mathrm{O}_{2} / \mathrm{kg}$ was fed, and the activity of serum aspartate aminotransferase and vitamin $A$ content of the liver (reduced when the peroxide value of dietary fat was $80 \mathrm{meq} \mathrm{O}_{2} / \mathrm{kg}$ ). A less sensitive indicator was erythrocyte superoxide dismutase activity, which did not increase until the peroxide value of dietary fat reached $160 \mathrm{meq} \mathrm{O}_{2} / \mathrm{kg}$. The degree of dietary fat oxidation did not have a significant effect on the activity of serum alanine aminotransferase, nor on the activities of AST, ALT, AP, LDH in the liver, serum and liver lipid profiles, or bone mineralization indicators. 


\section{REFERENCES}

Baynes J.W., 1991. Role of oxidative stress in development of complications in diabetes. Diabetes $40,405-412$

Corcos Benedetti P.C., M. D'Aquino, M. Di Felice, V. Gentili, B. Tagliamonte, G. Tomassi, 1987. Effects of a fraction of thermally oxidized soy bean oil on growing rats. Nutr. Rep. Int. 36, $387-401$

Cuesta Sanz D., Castro Santa-Gruz M., 1986. Simultaneous measurment of retinol and alpha-tocopherol in human serum by high performance liquid chromatography with ultraviolet detection. J. Chromatogr. 380, 140-144

Folch J., Lees M., Solane-Stanley G.H., 1957. A simple method for the isolation and purification of total lipids from animal tissue. J. Biol. Chem. 226, 497-507

Franson J.C., Murray H.C., Bunck C., 1985. Enzyme activities in plasma, kidney, liver, and muscle of five avian species. J. Wildlife Dis. 21, 33-39

Hayam I., Cogan U., Mokady S., 1993. Dietary oxidized oil enhance the activity of $\left(\mathrm{Na}^{+} \mathrm{K}^{+}\right)$ATPase and acetylcholinesterase and lowers the fluidity of rats erythrocyte membrane. J. Nutr. Biochem. 4, 563-568

Hayam I., Cogan U., Mokady S., 1995. Dictary oxidized oil and the activity of antioxidant enzymes and lipoprotein peroxidation in rats. Nutr. Res. 15, 1037-1044.

Hochgraf E., Mokady S., Cogan U., 1997. Dietary oxidized linoleic acid modifies lipid composition of rat liver microsomes and increases their fluidity. J. Nutr. 127, 681-686

Kehrer J.P., 1993. Free radicals as mediator of tissue injury and disease. Crit. Rev. Toxicol. 23, 21-48

Kirchgessner M., Roth H.P., Schliack M., 1993. Einfluss ungesättigter Diätfettsäuren auf die Verteilung von Cholesterin in den einzelnen Lipoproteinfraktionen und auf Serumlipide von Ratten. Z. Ernährungswiss. 32, 38-45

Lambert M.S., Avella M.A., Botham K.M., Mayes P.A., 1998. Comparison of short- and long-term effect of different dietary fats on the hepatic uptake and metabolism chylomicron remnants in rats. Brit. J. Nutr. 79, 203-211

Lopez-Varela S., Sanchez-Muniz F.J., Cuesta C., 1995. Decreased food efficiency ratio, growth retardation and changes in liver composition in rats consuming thermoxidized and polymerized sunflower oil used for frying. Food Chem. Toxicol. 33, 181-189

Matyka S., Korol W., 1991. Influence of various fat added to diets on retention of calcium, phosphorus and magnesium in broiler chicken (in Polish). Biul. inf. Przem. Pasz. 2, 23-36

Nagata Y., Imaizumi K., Sugano M., 1980. Effects of soya-bean protcin and casein on serum cholesterol levels in rats. Brit. J. Nutr. 44, 113-121

Nalbone N., Leonardi J., Termine E., Portugal H., Lechene P., Pauli A.M., Lafont H., 1989. Effects of fish oil, corn oil and lard diets on lipid peroxidation status and glutathione peroxidase activites in rat heart. Lipids $24,179-186$

Prasad N.N., Saraswathy S., 1996. Effect of vitamin E on the lipid peroxidation induced by polyunsaturated fatty acids vis-a-vis cholesterol in rats fed Indian army ration. Nutr. Res. 16, $1411-1424$

Rivetz B., Bogin E., 1982. Enzymatic changes in serum and tissues in fowl infected with a neurotropic - mesogenic strain of Newcastle disease virus. Avian Pathol. 11, 407-425

Sanchez-Muniz F.J., Lopez-Varela S., Garrido-Polonio M.C., Cuesta C., 1998. Dietary effects on growth, liver peroxides, and serum and lipoprotein lipids in rats fed a thermoxidised and polymerised sunflower oil. J. Sci. Food Agr. 76, 364-372 
Tomaszewski L., 1970. Biochemical Micromethods in the Clinical Laboratory (in Polish). PZWL, Warszawa, pp. 180-182

Uchiyama M., Mihara M., 1978. Determination of malonaldehyde precursor in tissues by thiobarbituric acid test. Anal. Biochem. 86, 271-278

Wachnik A., Biro G., Gaal O., Antal M., 1989. Dietary influence of the hepatic lipid peroxidation in two strains of rats. Nahrung 33, 687-689

Webb D.M., DeNicola D.B., Van Vleet J.F., 1991. Serum chemistry alterations, including creatine kinase isoezymes, in furazolidone toxicosis of ducklings: preliminary fidings. Avian Dis. 35, $662-667$

Yagi K., 1980. Toxicity of lipid peroxides in processed foods. Biochem. Rev., Golden Jubilee, $L, 42-46$

Zduńczyk Z., Juśkiewcz J., Długoszewska M., Frejnagel S., Koncicki A., 2000. The response of rats to long-term feeding with diets containing oxidized fat. 1 . Thermooxidative changes in fat, body weight gain, feed consumption and utilisation J. Anim. Feed Sci. 9, 139-148

\section{STRESZCZENIE}

Reakcja szczurów na dlugotrwale karmienie dietami zawierającymi utleniony tluszcz. 2. Wskaźniki biochemiczne surowicy i wątroby oraz mineralizacja kości

Oznaczono wybrane wskaźniki biochemiczne w krwi i wątrobie oraz mineralizację kości u szczurów żywionych przez 8 tygodni dietami zawierającymi 10\% tłuszczu o liczbie nadtlenkowej 5,40 , $80,120,160 \mathrm{i} 200 \mathrm{meq} \mathrm{O}_{2} / \mathrm{kg}$. Średnia masa ciała szczurów wynosiła $259,9 \mathrm{~g}$; grupy doświadczalne składały się z 12 zwierząt. Tłuszcz o wysokiej liczbie nadtlenkowej ( $160 \mathrm{i} 200 \mathrm{meq} \mathrm{O}_{z} / \mathrm{kg}$ ) powodował istotny wzrost koncentracji dialdehydu malonowego w surowicy krwi i niewielki wzrost w wątrobie. Najbardziej czułym wskaźnikiem rcakcji szczurów na utlenienie thuszczu diety była aktywność peroksydazy glutationowej w erytrocytach, która zwiększała się już przy najmniejszym stopniu utlenienia tłuszczu, tj. przy $40 \mathrm{meq} \mathrm{O}_{2} / \mathrm{kg}$, a także aktywność aminotransferazy asparaginianowej w surowicy i zawartość witaminy A w wątrobie, które obniżały się przy liczbie nadtlenkowej $80 \mathrm{meq} \mathrm{O}_{z} / \mathrm{kg}$. Stopień utlenienia tłuszczu nie miał istotnego wplywu na aktywność aminotransferazy alaninowej w surowicy, enzymy wątrobowe (transferaza asparaginianowa, aminotransferaza alaninowa, kwaśna fosfataza i dehydrogenaza kwasu mlekowego), poziom trójglicerydów w surowicy krwi i wątrobie, ogólną zawartość choresterolu i frakcję HDL, oraz na wskaźniki mineralizacji kości. 